\title{
KEDUDUKAN BANK INDONESIA (BI) SEBAGAI PEMOHON PAILIT SETELAH BERDIRINYA OTORITAS JASA KEUANGAN (OJK)
}

\author{
I Komang Mudita, I Nyoman Sujana, Desak Gde Dwi Arini \\ Fakultas Hukum Universitas Warmadewa, Denpasar-Bali, Indonesia \\ Muditakomang2@gmail.com,nyomansujanaa2015@gmail.com, arinidesak1966@gmail.com
}

\begin{abstract}
Abstrak
Lembaga perbankan sampai saat ini memiliki peran penting dalam kehidupan masyarakat. Setelah lahirnya Undang-Undang Nomor 21 Tahun 2011 tentang Otoritas Jasa Keuangan permasalahan mengenai wewenang Bank Indonesia menyatakan pailit suatu bank menjadi polemik serta sangatlah menarik untuk diteliti. Adapun tujuan penelitian ini yaitu mengetahui bagaimanakah Pertimbangan yang di ambil oleh Bank Indonesia Sebagai Pemohon Pailit setelah adanya Otoritas Jasa Keuangan dan Bagaimanakah Peran Bank Indonesia Dalam Menyelesaikan permohonan Pailit Terhadap Bank. Dalam Penelitian Ini Penulis Menggunakan Tipe Penelitian Normatif dari Sumber hukum primer bahan hukum skunder serta Sumber Hukum Tersier. Pasal 2 ayat (3) No. 37 Tahun 2004 tentang Kepailitan dan Penundaan Kewajiban Pembayaran Utang memberikan kewenangan tunggal kepada Bank Indonesia untuk mengajukan permohonan pailit kepada bank sebagai kreditor. hasil penelitian ini menunjukan bahwa kewenangan pengajuan permohonan pailit bank setelah berdirinya Otoritas Jasa Keuangan dimana OJK hanya ikut berperan dalam mempertimbangkan status bank yang akan dinyatakan pailit apakah memiliki dampak sistemik atau tidak. Otoritas Jasa Keuangan dapat meminta pertimbangan serta berkoordinasi dengan Bank Indonesia dalam penentuan dampak sistemik tersebut namun kewenangan Bank Indonesia dalam menyatakan permohonan pailit bank masih tetap ada.
\end{abstract}

Kata Kunci : Bank Indonesia; Kepailitan; Otoritas jasa keuangan

\begin{abstract}
Until now, banking institutions have played an important role in people's lives. After the issuance of Law Number 21 of 2011 concerning the Financial Services Authority, the issue regarding the authority of Bank Indonesia to declare bankruptcy of a bank became a polemic and very interesting to study. The purpose of this study is to find out how the considerations taken by Bank Indonesia as a Bankruptcy Applicant after the Financial Services Authority exist and what is the role of Bank Indonesia in completing bankruptcy applications against banks. In this study the author uses the type of normative research from primary legal sources, secondary legal materials and tertiary law sources. Article 2 paragraph (3) No. 37 of 2004 concerning Bankruptcy and Postponement of Debt Payment Obligations gave Bank Indonesia sole authority to apply for bankruptcy to the bank as creditor. The results of this study indicate that the authority to submit bankruptcy applications for banks after the establishment of the Financial Services Authority where OJK only plays a role in considering the status of a bank that will be declared bankrupt whether it has a systemic impact or not. The Financial Services Authority may ask for consideration and coordinate with Bank Indonesia in determining the systemic impact, however, the authority of Bank Indonesia in declaring bank bankruptcy applications still remains.
\end{abstract}

Keywords : Bank Indonesia; Bankruptcy; Financial services authority

\section{PENDAHULUAN}

Permohonan kepailitan terhadap bank pada dasarnya berbeda dengan lembaga lainnya karena karakteristik yang berbeda. Hal tersebut terjadi karena hanya Bank Indonesia yang diberikan kewenangan sesuai undang-undang untuk dapat mengajukan permohonan pailit terhadap suatu bank. Bank Indonesia (yang selanjutnya disebut BI) merupakan lembaga yang bersifat independen sekaligus dijadikan sebagai Bank Sentral Republik Indonesia karena hal tersebutlah BI bebas dari campur tangan Pemerintah dan/atau pihak lainnya kecuali untuk hal-hal yang secara tegas diatur dalam undangundang yang telah mengaturnya. 
BI memiliki otoritas besar untuk melakukan permohonan pailit suatu bank sehingga memegang peran kunci untuk mengatasi terkait utang piutang atau dalam hal perkara kepailitan. Untuk itu karena kewenangannya yang besar maka peranannya dalam keterlibatannya mengenai urusan kepailitan yang mana bank sebagai debiturnya. Karena fungsi bank untuk menghimpun serta menyalurkan dana kepada masyarakat maka BI disini yang memiliki otoritas untuk menetapkan kepailitan suatu bank karena untuk melindungi kepentingan masyarakat (Saroinsong, 2014).

Otoritas Jasa Keuangan mendapatkan pengalihan kewenangan pengawasan bank dari Bank Indonesia. Sehingga karena terbentuknya OJK inilah lembaga ini memiliki kewenangan terhadap suatu bank dalam mengajukan permohonan pernyataan pailit karena salah satu fungsinya yaitu mengawasi jalannya bank sehingga tau kondisi terkini dari suatu bank apakah sedang dalam kondisi baik atau tidak sehat. Selanjutnya juga menjalankan tugasnya untuk menilai suatu bank tersebut agar tetap melaksanakan prinsip kehati-hatian dan lembaga yang diberi kewenangan tersebut diwajibkan menjalankan kewenangan yang telah diperintahkan oleh aturan perundang-undangan (Janisriwati, 2011). Paying hukum untuk OJK adalah lahirnya Undang-Undang Nomor 21 Tahun 2011 yang mana telah diundangkan sejak tanggal 22 November 2011 untuk itu pengaturan dan pengawasan sektor perbankan yang pada mulanya berada pada Bank Indonesia telah beralih menjadi wewenang atau tugas Otoritas Jasa Keuangan.

Pengaturan Kepailitan Bank bilamana suatu bank dinyatakan pailit itu hanya dapat dilakukan oleh Bank Indonesia saja. Namun setelah adanya Otoritas Jasa Keuangan saat ini hal itu beralih kepadanya mengingat fungsi pengawasannya beralih kepada OJK jadi Bank Indonesia bekerjasama dengan Otoritas Jasa Keuangan dalam hal ini. Hal ini juga tercantum dalam Undang-Undang kepailitan.

Pengaturan kewenangan Bank Indonesia serta Otoritas Jasa Keuangan terdapat dalam Pasal 7 UU-OJK. Namun batasan wewenang macro prudential BI dengan macro prudentialnya dan OJK dengan microprudentialnya dirasa belum begitu jelas sehingga memiliki potensi terjadinya tumpangtindih over lapping terkait aturannya dan mengakibatkan tarik menarik kewenangan antara keduanya.

Berdasarkan penelitian terdahulu oleh (Ashinta Sekar, 2014) menyatakan bahwa Bank Indonesia mempunyai tugas dan wewenang dalam hal fungsi pembayaran, fungsi pengawasan dan menetapkan kebijakan moneter. Akhirnya setelah tertunda sekitar 10 tahun pada tahun 2011 akhirnya OJK telah terbentuk dengan disahkannya UU Nomor 21 Tahun 2011 Tentang Otoritas Jasa Keuangan. Dengan terbentuknya OJK yang menggantikan peran Bank Indonesia maka ada beberapa tugas dan wewenang BI yang dipangkas. Bank Indonesia hanya berwenang dalam hal menetapkan kebijakan moneter.

Adapun tujuan penelitian ini yaitu mengetahui bagaimanakah Pertimbangan yang di ambil oleh Bank Indonesia Sebagai Pemohon Pailit setelah adanya Otoritas Jasa Keuangan dan Bagaimanakah Peran Bank Indonesia Dalam Menyelesaikan permohonan Pailit Terhadap Bank.

\section{METODE PENELITIAN}

Dalam penelitian ini digunakan metode penelitian normatif dengan melalui pendekatan perundangundangan bersama dengan pendekatan secara konseptual. Adapun sumber bahan hukum yang digunakan adalah Peraturan Perundang- Undangan terkait seperti Undang-Undang Nomor 21 Tahun 2011 tentang Otoritas Jasa Keuangan Undang-undang Nomor 3 Tahun 2004 tentang Bank Indonesia Undang-Undang No. 37 Tahun 2004 tentang Kepailitan dan Penundaan Kewajiban Pembayaran Utang dan lainnya serta beberapa jurnal literature dan buku ilmiah terkait lainnya Penelitian ini ditujukan untuk menemukan aturan-aturan hukum yang dapat memberikan kejelasan mengenai permohonan pailit terhadap bank. Sumber data utama dalam penelitian ini adalah data sekunder dan terbagai atas bahan hukum primer, sekunder, dan tersier. Adapun teknik pengumpulan data yang digunakan yaitu teknik penelitian kepustakaan. Alat pengumpulan data yang digunakan adalah studi pustaka. Studi pustaka dilakukan untuk memperoleh data sekunder. Analisis data yang digunakan dalam penelitian ini adalah analisis kualitatif.

III. HASIL DAN PEMBAHASAN

1. Pertimbangan yang diambil Bank Indonesia (BI) sebagai Pemohon Pailit setelah Berdirinya Otoritas Jasa Keuangan (OJK) 
Bank Indonesia merupakan lembaga yang sifatnya independen dan merupakan Bank Sentral Republik Indonesia sehingga untuk itu Pemerintah dan/atau pihak- pihak lainnya tidak dapat turut campur tangan di dalam urusannya kecuali undang- undang secara tegas mengaturnya.

Sebagai lembaga yang independen BI mempunyai otoritas serta otonomi penuh untuk menjalankan tugasnya sebagai lembaga yang bersifat independen. Karena pemerintah yang tidak dapat turut campur dalam urusan BI sebagai lembaga independen ini mengakibatkan BI diharapkan mampu bebas dari intervensi pihak luar seperti pemerintah contohnyaUntuk hal tersebut diharapkan mampu menjaga menjaga stabilitas keuangan sehingga jika dikaitkan hal ini juga membantu untuk turut menjaga stabilitas sistem moneter di Indonesia (Sitompul, 2002).

Undang-Undang No. 10 Tahun 1998 tentang perubahan atas Undang-Undang No. 7 Tahun 1992 pada pasal 29 ayat (1) tentang Perbankan serta Undang-Undang No. 23 Tahun 1999 sebagaimana telah diubah dengan Undang-Undang No. 3 Tahun 2004 tentang Bank Indonesia pada pasal 8 tugas tanggung jawab serta wewean dalam pengawasan serta pembinaan bank menjadi urusan Bank Indonesia sehingga otoritas penuh ada pada Bank Indonesi. Karena terjadi proses globalisasi yang pesat khususnya dalam sistem keuangan serta kemajuan di bidang teknologi informasi termasuk inovasi finansial juga turut maju pesat sehingga system keuangan kompleks pun tercipta karenanya maka untuk itu berbagai sector saling terhubung dan terkait dan berjalan dengan dinamis antar lembaga keuangan (Sitompul, 2002).

Pembentukan Otoritas Jasa Keuangan bertujuan menyelenggarakan sector jasa keuangan yang sehat adil akuntabel transparan secara menyeluruh serta mewujudkan system keuangan yang terus bertumbuh secara kontinyu atau berkelanjutan hingga stabil guna memberikan perlindungan kepentingan bagi tiap masyarakat. Diharapkan dengan demikian OJK mampu mendukung berbagai kepentingan sektor jasa keuangan nasional dan nantinya mampu meningkatkan daya saing secara nasional. Selain itu kemampuan untuk menjaga kepentingan yang sifatnya nasional terkait jasa keuangan yang juga bebas dari campur tangan pihak lain juga diharapkan dari OJK (Yasinta, 2001).

Peran mikroprudensial milik Bank Indonesia beralih kepada Otoritas Jasa Keuangan seenjak lahirnya lembaga tersebut. Sehingga Bank Indonesia dapat fokus kepada regulasi di bidang moneter. dengan landasan prinsip manajemen yang terkelola dengan baik begitu juga dengan sifat akuntabilitas transparansi tanggung jawab serta keindependenannya inilah pembentukan OJK sesungguhnya. Untuk itu prinsip Check and Balances harus dimiliki oleh OJK sendiri ( $\mathrm{S}$ i a mat, 20111 ).

Karena wewenang permohonan pernyataan pailit ada pada Bank Indonesia semata-mata menyesuaikan dengan pengaturan dalam Undang-Undang No. 3 Tahun 2004 tentang Perubahan Atas Undang - Undang Republik Indonesia No. 23 Tahun 1999 tentang Bank Indonesia yang mana Bank Indonesia mengamanatkan terbentuknya Otoritas Jasa Keuangan. Karena hal tersebut pengambil alihan wewenang oleh Otoritas jasa Keuangan sebagai pelimpahan dari Bank Indonesia terkait dengan urusan mikroprudensial dalam industry perbankan sedangkan sector makronya masih dimiliki Bank Indonesia. Karena kewenangan pernyataan pailit suatu bank serta kemoneteran ekonomi termasuk dalam kewenangan makroprudensial

Dengan tetap mengacu Undang-Undang Kepailitan pasal 2 ayat (3) disebutkan bahwa kewenangan Bank Indonesia (BI) dalam mengajukan permohonan pernyataan pailit bank pada dasarnya semata-mata berdasarkan atas penilaian terhadap kondisi keuangan suatu bank dan perbankan secara keseluruhan. Hal tersebut juga ditegaskan dalam UU OJK bahwa hingga ketentuan penutup Undang-Undang OJK sehingga tidak ada tertulis terkait pengalihan kewenangan permohonan pernyataan pailit suatu bank tersebut.

Tugas serta kewenangan Otoritas Jasa Keuangan merupakan pelimpahan dari Bank Indonesia khususnya dalam ranah pengaturan maupun pengawasan suatu bank (Chandra, 2015). Namun hanyalah fungsi wewenang serta tugas yang dilimpahkan pada OJK oleh Bank Indonesia itulah yang diatur dalam Undang-Undang Otoritas jasa KeuanganBerdasarkan ketentuan Pasal 70 angka 7 Undang-Undang Otoritas Jasa Keuangan mengatur bahwa bank Indonesia masih tetap pada kewenangannya untuk menyatakan permohonan pailit suatu bank mengingat aturan perundangundangan yang masih berlaku yaitu undang-undang kepailitan pada pasal 2 ayat (3) sehingga masih menjadi urusan Bank Indonesia selagi belum dilimpahkan kepada Otoritas Jasa Keuangan. 


\section{Peran Bank Indonesia dalam Menyelesaikan Permohonan Pailit pada Bank}

Bank Indonesia memiliki kapasitas besar dan tujuan yang utama yaitu memelihara nilai rupiah serta melakukan pencapaian tersebut hal ini sesuai dengan kapasitasnya sebagai bank sentral di Indonesia. Bersama dengan dukungan tiga pilar yang adalah tugasnya sendiri Bank Indonesia mencapai tujuan tersebut antara lain dalam mengatur serta menjaga kelancaran lalu lintas pembayaran melaksanakan kebijakan moneter serta melakukan pengawasan bank. Untuk itu perlu pengintegrasian diantara ketiga bidang tersebut sehingga dapat mencapai dan memelihara kestabilan nilai rupiah dengan efisien dan efektif.

Terlihat adanya unsur preventif dalam kewenangna Bi melakukan pengawasan kepada bank karena tujuan dari pengawasan tersebut yaitu untuk mencegah serta menghindari terjadinya kekeliruan/penyimpangan seperti dalam persiapan melakukan kegiatan usaha setiap bank haruslah mendapatkan izin untuk mendirikan kelembagaannya dan yang diberikan izin hanyalah bank-bank yang telah memenuhi ketentuan.

Di bidang kepailitan keseluruhan kewenangankewenangnaBank Indonesia dapat dikatakan tidak terlalu sentral ini semua dikarenakan setelah didirikannya Otoritas Jasa Keuangan fungsi pengawasan terhadap bank bukan lagi menjadi kewenangan atau otoritas Bank Indonesia. Sehingga koordinasi terkait urusan kelembagaan harus dilakukan antara Bank Indonesia dan Otoritas Jasa Keuangan.

Dengan mengarah pada pasal 2 ayat (3) Undang-Undang no 37 tahun 2004 Tentang Kepailitan berikut peran Bank Indonesia dalam kepailitan yaitu dikatakan selaku pemohon tunggal (tak ada yang lain) untuk menyatakan pailit suatu bank. Ini semua untuk meyakini adanya kepastian hukum bagi masyarakat mengingat hukum berlaku secara universal atau umum. Dari sini kita ketahui cukup sulit mencapai keadilan serta kemanfaatan melihat pada sifat hukum yang universal dan umum sehinga lebih condong kepada tujuan kepastian hukumnya.

Melalui pengkaitan diantara ketentuan dalam Undang-undang No 21 Tahun 2008 Tentang Perbankan Undang-undang No 23 Tahun 2004 Tentang Bank Indonesia (BI) serta Undang-undang No 37 Tahun 2004 Tentang Kepailitan ditemukan beberapa cara untuk menangani bank bermasalah yaitu

a) Mencabut membubarkan dan melikuidasi bank yang gagal dan tidak sehat lagi

b) Pengajuan permohonan pernyataan pailit untuk bank yang gagal tersebut

Pada dasarnya tingkat kesehatan bank mencerminkan kondisi dari bank tersebut untuk masa yang akan dating. Dalam dunia perbankan sarana dalam menetapkan strategi dalam usaha di masa yang akan dating dibutuhkan penilaian kondisi suatu bank yang benar-benar detail dan menyeluruh selain itu dengan mengawasi suatu bank merupakan strategi untuk menetapkan kondisi suatu bank yang dilakukan oleh OJK. Penilaian kesehatan bank dipengaruhi oleh beberapa faktor yang diatur dalam Peraturan Bank Indonesia Nomor 13/1/Pbi/2011Tentang Penilaian Tingkat Kesehatan Bank Umum mengatur beberapa faktor yang dapat memengaruhi penilaian terhadap kesehatan suatu bank yang sebelumnya pengaturan terhadap kesehatan bank umum dilakukan berdasarkan Peraturan Bank Indonesia Nomor 6/10/Pbi/2004 Tentang Sistem Penilaian Tingkat Kesehatan Bank Umum.

Pengawasan terhadap bank secara khusus dapat dibagi menjadi dua untuk menetapkan suatu bank dapat dinyatakan pailit yaitu menetapkan status bank apakah berdampak sistemik dan satu lagi tidak berdampak sistemik. Bank dapat dinyatakan pailit jika bank tersebut tidak berdampak sistemik. Hal ini seperti pemberlakuan likuidasi suatu bank yang mungkin untuk dilakukan. Tindakan pemberesan asset jika telah dilakukannya keputusan mencabut izin usaha suatu bank dapat dikatakan mengarah kepada likuidasi bank inilah yang menjadi perbedaan besar dengan rangkaian kepailitan yang tidak dapat berujung pada mencabut izin usaha suatu bank gagal.

Bank Indonesia jika dianalisis sesuai legal standingnya untuk dapat melakukan permohonan pernyataan pailit suatu bank dapat dikatakan menjadi acuan bahwa masih tetap memiliki kewenangan tersebut. Sedangkan memberikan pertimbangan mengenai status bank yang akan dinyatakan pailit apakah berdampak sistemik atau tidak berdampak merupakan fungsi dan tugas OJK. Seperti yang telah dijelaskan sebelumnya bank yang tidak berdampak sistemik yang hanya dapat dimohonkan untuk dinyakatan kepailitannya.

Dengan melakukan kerjasama atau koordinasi bersama antara BI dan OJK dalam melakukan pertimbangan untuk menentukan dampak sistemik suatu bank yang akan dinyatakan pailit merupakan kewajiban bersama. Ini disebabkan wewenang makroprudensial masih dimiliki BI selaku bank 
sentral. Sehingga diharapkan dapat menjamin kepastian hukum dalam hal kewenangan menyatakan kepailitan suatu bank itu sendiri.

Kekacauan dalam sistem perekonomian berskala nasional dapat dihindari untuk terjadi jika sudah adanya kepastian hukum terkait wewenang dalam permohonan kepailitan untuk suatu bank dengan jawaban berdasarkan teori kepastian Bank Indonesia yang memiliki kewenangan makroprudensial yang berhak memohon kepailitan suatu bank gagal di Indonesiadi indoneisa. Karena sampai saat ini aturan dalam OJK tidak mengaturnya atau menyebutkannya maupun UU Kepailitan khususnya pasal 2 ayat (3) belum berubah dan masih berlaku sehingga tidak dapat dilaksanakan lain (Ali, 2002).

\section{SIMPULAN DAN SARAN}

\section{Simpulan}

Karena kerjasama Bank Indonesia denga Otoritas jasa Keuangan teradi dalam mempertimbangkan permohonan pernyataan pailit suatu bank setelah berdirinya Otoritas Jasa Keuangan masih menjadi urusan Bank Indonesia sebagai permohon pailit dasar pertimbangannya dapat dilihat dari ketentuan Undang-Undang Kepailitan dan Penundaan Kewajiban Pembayaran Utang pada Pasal 2 ayat (3) kedua Bank Indonesia yang merupakan Bank Sentral sehingga memiliki wewenang makroprudensial dan tugas dan wewenang inilah menjadikannya untuk menjaga stabilitas moneter secara nasional dan ketiga guna menjaga kepentingan masyarakat umum agar tidak mudah terjadi kepailitan pada suatu bank jika kreditor yang diberikan kewenangan untuk menyatakan permohonan pailit bank. Penyelesaian permohonan pailit suatu bank merupakan tugas dan wewenang Bank Indonesia (BI) hal ini didasarkan pada analisis ketika bank apakah mengalami kesulitan dalam keuangan yang pada prinsipnya tidak memiliki standar yang baku mengenai suatu bank yang dapat diajukan sebagai kategori pailit oleh Bank Indonesia. Namun dengan diundangkannya UndangUndang No. 9 Tahun 2016 tentang Pencegahan dan Penanganan Krisis Sistem Keuangan bank yang gagal tidak berdampak sistemik dikategorikan sebagai bank yang dapat diajukan permohonan pailit Dampak kepailitan dirasa juga oleh masyarakat secara psikologis yang takut kehilangan dananya. Sehingga timbul suatu dorongan untuk melakukan likuidasi guna pengamanan dana yang mereka miliki untuk dipindahkan keakun bank lain yang masih sehat. Dari hal inilah timbul istilah bank panic dan rush. Dampak sistemik dapat muncul karena kegagalan bank sehingga dapat memicu keadaan system moneter yang tidak stabil dan mengalami krisis. Untuk itu maka hal tersebut dapat disandingkan dengan teori utilitarian. Berdasarkan legal standing untuk permohonan pernyataan pailit masih dipegang Bank Indonesia dengan tetap menjaga koordinasi antara keduanya yaitu Bank Indonesia dengan Otoritas Jasa Keuangan hal ini berdasarkan analisis peran dari BI sendiri. OJK hanya dapat mempertimbangkan status bank mengenai hal terkait kepemilikan dampak sistemik jika dinyatakan pailit nantinya. Karena hanya bank yang tidak memiliki dampak sistemik yang dapat untuk dimohonkan pernyataan pailitnya sesuai pengaturan substansial. Untuk itu dengan mempertimbangkan dan berkoordinasi antara OJK dan BI dapat menentukan dampak sisitemik dari suatu bank yang dianggap telah gagal. Hal ini sesuai dengan dasar bahwa BI dengan kewenangan makropudensialnya tetap memiliki kewenangan untuk melakukan permohonan pernyataan pailit suatu bank. Sedangkan dalam menentukan dampak sistemik suatu bank yang gagal dilakukan atas pertimbangan dan koordinasi antara OJK dengan BI. Sehingga kepastian hukumnya lebih jelas

\section{Saran}

Kepada Pemerintah Diharapkan adanya Peraturan dan Undang-Undang Nomor 3 tahun 2004 Tentang Bank Indonesia dan Undang undang Nomor 37 tahun 2004 tentang Kepailitan dapat menegaskan tentang pengajuan permohonan pailit suatu bank berada pada otoritas Bank Indonesia. Karena pada praktenya bank yang dapat dimohonkan pailit harus melalui proses yang sulit dan panjang. Dan masih banyak kebingungan atau ambiguitas terkait wewenang Bank Indonesia dengan Otoritas Jasa Keuangan yang dirasakan. Diharapkan adanya Undang-Undang atau Peraturan Internal Bank Indonesia yang khusus mengatur tentang adanya indikasi bank yang dirasa bermasalah sehingga dapat diajukan permohonan pailit. Serta adanya regulasi khusus mengenai koordinasi antara Otoritas Jasa Keuangan dan Bank Indonesia dalam hal mengajukan permohonan pailit suatu bank guna sematamata penjaminan adanya kepastian hukum 


\section{DAFTAR PUSTAKA}

Ali, A. (2002). Menguak Tabir Hukum (Suatu Kajian Filosofis dan Sosiologis). Penerbit Toko Gunung Agung.

Ashinta Sekar, B. (2014). Kedudukan Bank Indonesia (BI) Setelah Terbentuknya Otoritas Jasa Keuangan (OJK). Universitas Surakarta, 3(1).

Chandra, M. J. A. (2015). Kewenangan Bank Indonesia Dalam Pengaturan Dan Pengawasan Perbankan Setelah Terbitnya Undang-Undang No 21 Tahun 2011 Tentang Otoritas Jasa Keuangan. Jurnal Hukum Sehasen, 1(1).

Janisriwati, S. (2011). Kepailitan Bank (Aspek Hukum Kewenangan Bank Indonesia dalam Kepailitan Suatu Bank). Logoz Publishing.

Saroinsong, A. N. (2014). Fungsi Bank dalam Sistem Penyaluran Kredit Perbankan. Lex Privatum, 2(3).

Siamat, D. (2011). Kajian Hukum Penyelesaian Kredit Bermasalah dengan Bank. PT.Citra Inti Grafika.

Sitompul, Z. (2002). Perlindungan Dana Nasabah Bank Suatu Gagasan tentang Pendirian Lembaga Penjaminan Simpanan di Indonesia. FH UI Jakarta.

Yasinta, W. (2001). Rencana Pemisahan Fungsi Pengawasan Bank dari BI (Suatu Analisis). Penebar Swadaya Grup. 